\title{
Climate Change and Inequality: How to Solve These Problems Jointly? ${ }^{1}$
}

\author{
L. Grigoryev, I. Makarov, A. Sokolova, V. Pavlyushina, I. Stepanov
}

Leonid M. Grigoryev, Professor, Academic Supervisor, School of World Economy, National Research University Higher School of Economics; 20 Myasnitskaya Ulitsa, 101000, Moscow, Russian Federation; E-mail: lgrigor1@yandex.ru

Igor A. Makarov, Head, School of World Economy, National Research University Higher School of Economics; 20 Myasnitskaya Ulitsa, 101000, Moscow, Russian Federation; E-mail: imakarov@hse.ru

Anna K. Sokolova, Junior Research Fellow, Centre for Comprehensive European and International Studies, National Research University Higher School of Economics; 20 Myasnitskaya Ulitsa, 101000, Moscow, Russian Federation; E-mail: aksokolova@hse.ru

Victoria A. Pavlyushina, Junior Research Fellow, Laboratory for Climate Change Economics, National Research University Higher School of Economics; 20 Myasnitskaya Ulitsa, 101000, Moscow, Russian Federation; E-mail: pa_victoria@mail.ru

Ilya A. Stepanov, Junior Research Fellow, Laboratory for Climate Change Economics, National Research University Higher School of Economics; 20 Myasnitskaya Ulitsa, 101000, Moscow, Russian Federation; E-mail: iastepanov@hse.ru

\begin{abstract}
In recent decades, economic growth in developing economies and the growth of the middle class lead to a surge in energy consumption and greenhouse gas emissions. Within the framework of the United Nations (UN) sustainable development goals established in 2015, the solution to poverty and inequality thus comes into conflict with climate change mitigation.

The existing international system of climate regulation does not address this contradiction. Today, global climate governance relies on estimates of aggregate emissions by countries without considering their level of development and the distribution of emissions among income groups within each country. Emissions from production are being monitored, while consumption-related emissions, albeit known to experts, rarely underlie decision-making. Meanwhile, income distribution has a higher impact on consumption-based emissions in comparison to production-based ones. Decisions on emissions regulation are made at the national level by countries with different development agendas in which climate change mitigation often gets less priority in comparison to other socio-economic objectives.

This paper proposes a set of principles and specific mechanisms that can link climate change and inequality within a single policy framework. First, we highlight the need to modify the global emission monitoring system for the sake of accounting for emissions from consumption (rather than production) by income groups. Second, we suggest the introduction of a new redistribution system to address climate change which would include the imposition of a "fine" on households with the highest levels of emissions. Such a system follows the principles of progressive taxation but supports climate mitigation objectives and should be understood not as taxation of high incomes but rather as payment for a negative externality. Third, we outline the need to adjust climate finance criteria; priority should be given to projects designed to reduce carbon-intensive consumption by social groups entering the middle class, or to help the poorest population groups adapt to climate change. A special role in the implementation of these principles may belong to BRICS (Brazil, Russia, India, China and South Africa), which may view this as an opportunity for a proactive transition to inclusive, low-carbon development.
\end{abstract}

Key words: climate change; inequality; energy consumption; greenhouse gas emissions; sustainable development

For citation: Grigoryev L., Makarov I., Sokolova A., Pavlyushina V., Stepanov I. (2020) Climate Change and Inequality: How to Solve These Problems Jointly? International Organisations Research Journal, vol. 15, no 1, pp. 7-30 (in English). DOI: 10.17323/1996-7845-2020-01-01.

${ }^{1}$ The editorial board received the article in August 2019. 


\section{Introduction}

In global governance research and practice, problems of climate change are traditionally considered at the country level, and do not engage the question of the distribution of responsibilities for emissions within countries. However, the dynamics of global emissions are determined not only by countries, but by specific population groups within them - primarily groups with relatively high incomes and corresponding consumption patterns.

High household incomes in developed countries and the increasing incomes of the wealthiest population groups in developing economies lead to high and ever-growing energy consumption - by the transportation sector and households, by companies producing consumer goods for their needs, and by the government producing public goods. This consideration may seem trivial, but the dynamics of emissions should be considered, raising the question of what happens when a country or a social group moves from relative poverty to a higher level of income.

At the country level, climate change is often analyzed with regard to the stage of a country's industrialization, and its progress transitioning to a post-industrial economy [Bell, 1976]. Developed counties have to a large extent finished this transition. Rapid economic growth in recent decades has brought many "third world" countries out of extreme poverty. Leading developing countries such as China, Brazil, and the countries of Southeast Asia have achieved significant success in moving toward a decent standard of living [Grigoryev, Pavlyushina, 2018].

If we measure the progress in gross domestic product (GDP) per capita growth and the success in overcoming poverty, the world, of course, shows good results [Grigoryev, 2016]. However, the question arises: is the world moving toward sustainable development, in particular toward achieving the sustainable development goals (SDGs) approved by almost 150 countries for 2030? One of the key problems is how to link the observed increase in incomes and the associated increase in energy consumption with climate change mitigation, and in particular, with the need to limit the global temperature rise to $2^{\circ} \mathrm{C}$ above pre-industrial levels, which is the goal set by the Paris Agreement [2015].

By 2018, global GDP (purchasing power parity (PPP), constant 2011 Intl\$) increased by $155 \%$ compared to 1992, and GDP per capita went up by $78 \%$ [World Bank, n. d.]. Of course, the efficiency of production and consumption has significantly increased, and for this reason greenhouse gas emissions increased only $55 \%$ by the end of this period, reaching a plateau in recent years [Olivier, Peters, 2018]. But the result is far from sufficient: in order to achieve the 2-degree target, zero net carbon emissions are needed.

Taking into account the current state of international cooperation and technical progress, a solution to the climate change problem is impeded by the following issues:

- not all clean technologies with the necessary parameters will be invented in time;

- not all invented technologies will be available where they are most needed due to the mechanisms to protect intellectual property rights;

- funding of the ambitious objectives of climate change mitigation and adaptation is still a problem that has not been resolved in international climate negotiations;

- measures to cope with climate change in a number of developed and developing countries depend on electoral cycles that are difficult to synchronize to jointly solve global problems; and

- the ability of world elites to compromise in order to solve global problems is limited, which is reflected in geopolitical conflicts, in the slow decision-making process of the United Nations Framework Convention on Climate Change (UNFCCC) [1992], and the framework nature of the Paris Agreement [2015].

This paper argues that climate action (SDG 13) should be considered together with the task of reducing inequality (SDG 10). This paper outlines a system of principles bridging solu- 
tions to these two problems within a single policy framework. It is not the first attempt of this kind. For instance, L. Chancel and T. Piketty [2015] underline the importance of progressive carbon taxation and provide a positive example of a global tax on air tickets; however, this is too limited to serve as a global solution. J. Davies, X. Shi and J. Whalley [2014] consider a hypothetical global carbon tax, income from which is supposed to be redistributed among the poor in order to mitigate significantly the effects of carbon regulation on inequality. However, the authors themselves recognize that such a tax is a practical impossibility under the existing system of global governance.

Our proposal is based on a more feasible decile approach to the regulation of carbon emissions, suggesting that different regulatory instruments should be used for different income groups - from early warning measures for deciles which only approach the middle-class level to a full-fledged climate tax for wealthy strata. Under such a system of measures, taxes on consumption by wealthy social groups could be the main source of funds for climate change mitigation and adaptation worldwide. Further allocation of these funds could be focused on providing access to clean technologies and green consumption practices to social groups that are on the verge of transition to a "consumer society," as well as supporting adaptation to climate change in poor countries, where it causes the greatest damage to the population.

In addition to accumulating funds to address climate change, the proposed system of measures would contribute to a more equitable distribution of income, aiming to solve the systemic problem of growing inequality. It is essentially an alternative to the system of global progressive taxation that has been discussed widely in the last few years [Piketty, 2014]. However, it is an alternative which is comprehensive and fair. First, the system proposed in this paper can be interpreted as a compensation for negative externalities necessary to solve a global problem, rather than as an income tax. Second, it focuses on segments of society that have the financial resources not only for consumption but also to solve global problems. It is fundamentally important that this applies not only to developed but also to emerging economies, where the high-income groups may well share the responsibility for emissions with similar strata in the developed world.

The BRICS grouping of Brazil, Russia, India, China and South Africa may play a crucial role here. It is they who represent a substantial share of the world's poor and are among the world's largest emitters. At the same time, they have growing middle classes, which are adopting western-style patterns of consumption, and also some wealthy strata with incomes comparable to those of the wealthiest strata in the developed countries.

The paper is structured as follows. First, it provides an overview of theoretical ideas about the relationship between income growth (and related inequality growth) and emissions. Then, it demonstrates how income distribution is related to the distribution of emissions in practice, using the cases of four countries that provide a fairly diverse coverage. Reasons are discussed for the limited ability of the current climate regime to respond to rising incomes and the transition of large population groups in developing countries to the middle class. A number of principles aimed at improving the international climate change regime are proposed, and several conclusions are offered.

\section{The Relationship Between Income and Greenhouse Gas Emissions: An Overview}

The simplest way to show the interrelation between human impact on the environment and the level of income is the IPAT model (where impact (I) is the product of population (P), affluence (A) and technology (T)) [Ehrlich, Holdren, 1971], which was later adapted to the case of greenhouse gases [Kaya, 1989]: 


$$
E=P \times \frac{Y}{P} \times \frac{E}{Y}
$$

where $E=$ emissions, $P=$ population, $Y=$ GDP, $\frac{Y}{P}=$ GDP per capita and $\frac{E}{Y}=$ carbon intensity of GDP.

Based on this identity, it can be inferred that as the population and GDP inevitably grow on a global scale it is necessary to reduce carbon intensity in order to combat climate change, which is possible through technological development [Gates, Gates, 2016]. This is already partially implemented in practice. However, technological innovations occur mainly in developed countries, where population growth is minimal or even negative, while income growth is small. At the same time, in developing countries growing populations living in expanding economies are engaged in economic activity using the old and less energy-efficient technologies which are largely responsible for emissions growth [Han, Chatterjee, 1997]. Therefore, it is important to develop new technologiesprimarily in the leading developing countries.

In reality the story is more complicated: a growing population in the poorest countries, even with outdated technologies, has a minimal impact on emissions due to the extremely low level of consumption. To take into account the difference in consumption, instead of the IPAT model it is more appropriate to use the ICAT model, where C denotes consumption, or the ImPACT model [Waggoner, Ausubel, 2002; York, Rosa, Dietz, 2003] which in terms of greenhouse gas emissions can be presented as follows:

$$
E=P \times \frac{Y}{P} \times \frac{C}{Y} \times \frac{E}{C},
$$

where $C$ = consumption, $\frac{C}{Y}=$ consumption rate, $\frac{E}{C}=$ the intensity of carbon consumption

The main danger for the climate is not demographic or economic growth, but rather growth in the number of consumers who are adopting a lifestyle with a higher carbon footprint while still using outdated technologies. The growing numbers of such consumers in China, India and other leading emerging economies has resulted in an increase of emissions in recent decades, and this will determine the dynamics of emissions in the future. The international climate regime that concentrates on country-level emission estimates does not take this factor into account.

Another important instrument that can be used to examine the connection between emissions and income is the environmental Kuznets curve. Many scholars have tested the hypothesis that the relationship between emissions per capita and incomes has an inverted U-shaped curve (for an overview, see D. Kaika and E. Zervas [2013a; 2013b]). The environmental Kuznets curve reflects the argument that structural changes are the result of growth in income per capita: in the beginning, an extensive expansion of production contributes to per capita growth and leads to a rapid increase in greenhouse gas emissions. However, after reaching a certain income level, the sectoral structure of the economy changes and becomes led by services. More modern, cleaner technologies are introduced, and both people and government begin to place a higher value on the environment, while dirty industries are transferred to lower-income countries [Van Alstine, Neumayer, 2010].

However, the environmental Kuznets curve is a theoretical hypothesis and empirical testing in the case of greenhouse gas emissions yields very contradictory results [Kaika, Zervas, 2013a; 2013b]. In most cases, as income increases, emissions increase as well. Most empirical studies come to the conclusion that the world is still far from the point at which emissions would be expected to decline. Further, they conclude that this can be achieved only with a level of 
income per capita that will remain unattainable for most of the world's population for several decades [Stern, 2015; Uchiyama, 2016].

Most of the estimates of the environmental Kuznets curve are applied to production-based emissions. But it is even more interesting to test the curve for consumption-based emissions those associated with the production of all goods consumed in a country, including those that are produced abroad and then imported. Such estimates show no inverted U-shaped form at all: consumption-based emissions increase monotonically with the rise of incomes [Makarov, 2018; Mir, Storm, 2015]. The more a country or social group consumes, the more emissions it produces.

This idea has encouraged the bulk of research on carbon inequality; evidence shows that wealthier social groups are responsible for much greater emissions than poorer ones [Chancel, Piketty, 2015; Gore, 2015]. Chancel and Piketty [2015] revealed the significant rise of such inequality within countries over the last decades with a simultaneous decrease of carbon inequality between countries. The rise of carbon inequality is especially rapid in emerging economies, where incomes have been growing rapidly over the last few decades but the elasticity of emission by income is not decreasing. In China, the poorest households historically consumed so little energy that they produced almost no emissions (only $10 \%$ of all emissions come from the 10th decile), while the top 50\% are responsible for over $80 \%$ [Li, Wang, 2010]. In India, relatively wealthy households (with income of $\$ 10$ per capita per day and higher) emit twice as much in volume as all other households combined [Grunewald et al., 2012]. These two examples are representative of other countries with similar levels of development. This means that further income growth in these countries, which will lift large numbers of people out of poverty, will be accompanied by a huge increase in emissions despite positive trends in the energy efficiency of firms and household consumption.

Thus, climate change mitigation and coping with poverty and inequality are in many ways mutually exclusive goals - in the modern world, success in addressing one challenge inevitably leads to the aggravation of the other.

\section{The Relationship Between the Dynamics of Income and Greenhouse Gas Emissions}

The increase in energy consumption and related greenhouse gas emissions on the path from poverty to prosperity is uneven. First comes the transition from energy poverty to minimal energy consumption, a transition that significantly improves living standards but has little effect on global emissions. A more radical shift in the type of consumption occurs when a social group enters the middle class. This creates an increase in demand for heating and cooling of residential and public buildings, an active use of transport based on fossil fuels, and an increase in demand for final consumer goods and services, from meat to travel. The intermittent increase in energy consumption at the stage of the expansion of the middle class leads to lifestyle changes at the level of the household and society as a whole.

So far, relatively few studies focusing on the distribution of emissions by population groups have been published. According to B. Milanovic [2016], "there is an unevenness in carbon emissions that is seldom recognized and on which empirical research is lacking, despite the availability of data. One could easily estimate the distribution of $\mathrm{CO}_{2}$ emissions across the world population by income group and not, as is done today, by country. If income elasticity of carbon emissions is unitary (i.e., a 10\% increase in real income entails a $10 \%$ increase in carbon emissions), then the Gini coefficient of global carbon emissions is around 70 points, which would mean that more than one-half of all emissions are made by the global top $10 \%$. Almost 
all the people in the top world decile come, as we know, from rich countries. Not from Africa." T. Gore [2015] provides very similar estimates: $10 \%$ of the world's most affluent population actually produces almost half of global emissions. Chancel and Piketty [2015] made the same calculations using elasticities $0.7,0.9$ and 1.1 and obtained similar results (Table 1).

Table 1. Share of $\mathrm{CO}_{2}$ Emissions Concentration, $2013(\%)$

\begin{tabular}{|c|c|c|c|c|c|c|}
\hline Elasticity & Top 1\% & Top 5\% & Top 10\% & Middle 40\% & Bottom 50\% & Bottom 10\% \\
\hline 0.9 & 13.8 & 31.5 & 45.2 & 41.8 & 13.0 & 1.2 \\
\hline 0.7 & 9.9 & 26.6 & 40.0 & 44.8 & 15.3 & 1.5 \\
\hline 1.1 & 19.0 & 38.0 & 51.3 & 38.0 & 10.7 & 0.9 \\
\hline
\end{tabular}

Source: [Chancel, Piketty, 2015].

A consideration of global carbon inequality helps to describe a general picture, but it has limited practical value. It is more important to monitor distribution of emissions within individual countries. A database of emissions related to a quintile/decile has yet to be formed. However, it is possible to examine individual countries using data taken from various sources. In some cases, the data describes emissions, in others it shows energy consumption, closely correlated with emissions.

Table 2 shows data for the United States. It demonstrates that the emissions of the first quintile of the population are already very high (approximately equal to emissions of an average person in France), while per capita emissions for the third quintile are much higher than per capita emissions in almost all countries.

Table 2. The U.S. Average Household Income and $\mathrm{CO}_{2}$ Emissions per Quintile, 2002-04

\begin{tabular}{|c|c|c|c|}
\hline Quintile & Income (\$ Thousands) & Emissions (t) & $\begin{array}{c}\text { GDP per Capita, PPP 2000, } \\
\text { Intl\$ Thousands }\end{array}$ \\
\hline 1 & 13.7 & 4.7 & 12.3 \\
\hline 2 & 24.6 & 7.1 & 24.5 \\
\hline 3 & 36.0 & 9.2 & 35.8 \\
\hline 4 & 52.1 & 11.4 & 51.3 \\
\hline 5 & 102.4 & 18.5 & 106.0 \\
\hline Average & 45.8 & 10.2 & 51.0 \\
\hline
\end{tabular}

Sources: [Shammin, Bullard, 2009; World Bank, n. d. (authors' calculations)].

The data for the United Kingdom (Table 3) is similar to the data for the United States. Already, for the second decile of income distribution, the levels of wealth and energy consumption are high by global standards.

The U.S. and UK examples provide an idea of the nature of the distribution of income, consumption and emissions in the Anglo-Saxon world. Mexico has an above-average level of development, characterized by high income inequality and inequality in energy consumption (Table 4). For example, the emissions of the fifth quintile exceed emissions of the first by 4.5 times. The tenth decile in Mexico has an income of more than $\$ 60,000$ per capita, which is 
significantly higher than the average income in developed countries. Patterns of consumption for this decile are not significantly different from the western ones (although it is less carbonintensive in comparison to Anglo-Saxon countries).

Table 3. Average Annual Energy Consumption per Household by Decile (kW*h) in the UK, 2004-07

\begin{tabular}{|c|c|c|c|c|}
\hline Decile & Electricity & Gas & Total & $\begin{array}{c}\text { GDP per Capita, } \\
\text { PPP 2008, Intl\$ Thousands }\end{array}$ \\
\hline 1 & 2.608 & 8.758 & 11.366 & 9.9 \\
\hline 2 & 2.967 & 10.631 & 13.598 & 16.8 \\
\hline 3 & 3.204 & 11.767 & 14.971 & 23.0 \\
\hline 4 & 3.510 & 12.750 & 16.260 & \multirow{2}{*}{31.0} \\
\hline 5 & 3.715 & 14.259 & 17.974 & \multirow{2}{*}{42.5} \\
\hline 6 & 3.942 & 14.497 & 18.439 & 57.6 \\
\hline 7 & 4.263 & 15.538 & 19.801 & 99.7 \\
\hline 8 & 4.393 & 16.498 & 20.891 & \\
\hline 9 & 4.845 & 17.815 & 22.660 & \\
\hline 10 & 5.585 & 20.670 & 26.255 & 18.221 \\
\hline Average & 3.903 & 14.318 & 16.839 & \\
\hline Median & 3.426 & 13.413 & & \\
\hline
\end{tabular}

Source: [White, Roberts, Preston, 2010; World Bank, n. d. (authors’ calculations)].

Table 4. $\mathrm{CO}_{2}$ Emissions From the Household Use of Main Types of Home Equipment by Emission Deciles (Mt of $\mathrm{CO}_{2}, \%$ ) in Mexico, 2006

\begin{tabular}{|c|c|c|c|c|c|}
\hline Decile & $\begin{array}{c}\text { Decile's } \\
\text { Emissions, } \\
\text { Mt of CO }\end{array}$ & $\begin{array}{c}\text { Decile's } \\
\text { Share in Total } \\
\text { Emissions, \% }\end{array}$ & $\begin{array}{c}\text { Decile's Share in } \\
\text { Total Income, \% }\end{array}$ & $\begin{array}{c}\text { Emissions per } \\
\text { Household, t CO }\end{array}$ & $\begin{array}{c}\text { GDP per Capita } \\
\text { at PPP 2008, } \\
\text { Intl\$ Thousands }\end{array}$ \\
\hline 1 & 1.3 & 2.8 & 1.2 & 0.5 & 2.8 \\
\hline 2 & 2.1 & 4.4 & 2.7 & 0.8 & 4.7 \\
\hline 3 & 2.8 & 5.9 & 3.8 & 1.1 & \multirow{2}{*}{7.0} \\
\hline 4 & 3.3 & 6.9 & 4.8 & 1.2 & \multirow{2}{*}{10.2} \\
\hline 5 & 3.8 & 8.1 & 5.9 & 1.4 & \multirow{2}{*}{15.4} \\
\hline 6 & 4.4 & 9.3 & 7.3 & 1.7 & 24.0 \\
\hline 7 & 5.0 & 10.6 & 9.1 & 1.9 & 61.5 \\
\hline 8 & 5.9 & 12.4 & 11.8 & 2.2 & 15.8 \\
\hline 9 & 7.0 & 14.7 & 16.4 & 2.6 & 3.2 \\
\hline 10 & 8.5 & 17.8 & 37.1 & 1.7 & \\
\hline Total & 44.0 & $92.9^{*}$ & 100 & & \\
\hline
\end{tabular}

Source: [Rosas, Sheinbaum, Morillon, 2010; World Bank, n. d. (authors' calculations)].

Note: $*$ Not $100 \%$ of household emissions can be distributed by deciles. 
The data for China is generalized and fragmented (Table 5). It demonstrates that the share of emissions of the tenth decile is six times higher than the average share of emissions in the second-fifth deciles. The tenth decile creates $28.3 \%$ of national emissions. It is possible that, due to income growth in recent decades, the ninth and even eighth decile (reflected in Table 5 as part of the top 40\%), could achieve the same level of consumption and related emissions now or in the near future.

Table 5. Distribution of CO2 Emissions in China by Income Group, 2002

\begin{tabular}{|l|c|c|c|c|c|}
\hline \multicolumn{1}{|c|}{ Grouping* } & $\begin{array}{c}\text { Tons of } \mathbf{C O}_{2} \\
\text { per Capita }\end{array}$ & $\begin{array}{c}\text { Share of } \\
\text { Population, \% }\end{array}$ & $\begin{array}{c}\text { Share of } \\
\text { Emissions, \% }\end{array}$ & $\begin{array}{c}\text { Annual Consumption } \\
\text { Expenses (RMB } \\
\text { per Capita) }\end{array}$ & $\begin{array}{c}\text { GDP per Capita } \\
\text { at PPP 2008, } \\
\text { \$ Thousands }\end{array}$ \\
\hline 10th Decile & 6.3 & 7.6 & 28.3 & 9.974 & 25.3 \\
\hline Top 40\% & 2.5 & 35.6 & 51.8 & 4.831 & \\
\hline Bottom 40\% & 0.7 & 44.0 & 18.3 & 1.727 & \\
\hline 1st Decile & 0.2 & 12.8 & 1.6 & 864 & 1.6 \\
\hline
\end{tabular}

Source: [Li, Wang, 2010; World Bank, n. d. (authors' calculations)].

Note: *In the source "decile" means not one tenth of the population, but a group of people with significantly different incomes, whose number is close to one tenth.

The data for these four countries is very fragmentary. However, even these statistics are enough to form a picture describing realities of the global distribution of emissions by income groups.

We do not have enough data on the BRICS countries to create a reliable picture of the distribution of emissions among income groups. But it is these countries that will be responsible for most of the increase of global emissions in coming decades. This increase will be determined primarily by the expansion of the middle class with western-style consumption patterns and the rising consumption of the top income deciles.

The BRICS group consists of economies with substantial differences in the level of development and economic growth models. China, while being comparable in population with India, produces almost 2.5 times as much per GDP (PPP). The dispersion of GDP (PPP) per capita in current prices within BRICS was 3.9 times greater in 2017. At the same time, South Africa demonstrates the highest social inequality, while being in the middle of the distribution. In 2017, the share of income in the wealthiest (10th) decile was $50.5 \%$ in South Africa, $40.4 \%$ in Brazil, $31.4 \%$ in China, $29.8 \%$ in India and $29.7 \%$ in Russia.

BRICS countries are the first that are shifting from low and middle to high incomes in a world constrained by concerns about emissions and fossil fuels. If they make this shift using conventional development models and following western consumption patterns, we will definitely have a climate catastrophe. Therefore, the crucial question of global climate action is whether Brazil, Russia, India, China and South Africa are able to adopt climate-friendly pathways on their way to prosperity which could be later used as a template for less-developed countries like Indonesia and those in Sub-Saharan Africa. 
Table 6. Inequality in BRICS and Population, 2017*

\begin{tabular}{|c|c|c|c|c|c|c|c|c|}
\hline & \multicolumn{7}{|c|}{ Income Share } & \multirow{2}{*}{$\begin{array}{l}\text { Population, } \\
\text { Millions }\end{array}$} \\
\hline & $\begin{array}{c}\text { Highest } \\
10 \%\end{array}$ & $\begin{array}{c}\text { Highest } \\
20 \%\end{array}$ & $\begin{array}{c}\text { Fourth } \\
\mathbf{2 0 \%}\end{array}$ & $\begin{array}{l}\text { Third } \\
20 \%\end{array}$ & $\begin{array}{c}\text { Second } \\
20 \%\end{array}$ & $\begin{array}{c}\text { Lowest } \\
20 \%\end{array}$ & $\begin{array}{c}\text { Lowest } \\
10 \%\end{array}$ & \\
\hline Brazil & 41.9 & 57.8 & 19.5 & 12.2 & 7.4 & 3.2 & 1 & 209.5 \\
\hline Russia & 29.7 & 45.3 & 21.5 & 15.2 & 11.1 & 6.9 & 2.8 & 144.5 \\
\hline India & 30.1 & 44.4 & 20.5 & 15.2 & 11.7 & 8.1 & 3.5 & 1352.6 \\
\hline China & 29.4 & 45.4 & 22.3 & 15.3 & 10.6 & 6.4 & 2.6 & 1392.7 \\
\hline South Africa & 50.5 & 68.2 & 16.5 & 8.2 & 4.8 & 2.4 & 0.9 & 57.8 \\
\hline
\end{tabular}

Source: [World Bank, n. d.].

Note: *Or latest available year.

\section{The Current Climate Change Regime and Its Shortcomings}

Coping with global climate change requires the coordination of efforts among all leading countries. The main document that declares the objective to combat climate change is the UN Framework Convention on Climate Change adopted in 1992 [UNFCCC, 1992]. The quantitative commitments to achieve this objective were specified in the Kyoto Protocol adopted in 1997.

The Kyoto Protocol played an important role in the development of international climate cooperation, but it was ineffective in and of itself. Its targets were too weak, and it was unable to consider the major shifts that occurred in the world economy in the 1990-2000s. These shifts included the deep structural crises in economies in transition, and the transformation of a number of developing countries into developed ones (for example, Korea and Singapore). And most importantly, being concentrated on wealthy countries, the Kyoto Protocol did not adequately address the challenge of rapid economic growth in India, and especially in China, which transformed these countries into leading emitters of greenhouse gases. From 1990 to 2012, China and India increased greenhouse gas emissions by 3.6 and 2.4 times, respectively. This increase more than offset the reduction of emissions in developed economies.

In 2015, the Kyoto Protocol was replaced by the Paris Agreement, which has already entered into force, having been ratified by 189 countries to date. Unlike the Kyoto Protocol, it is non-binding in terms of emissions reduction, but it is universal: it includes developing countries as full participants. In addition, the Paris Agreement is based on the bottom-up principle: countries themselves set their own emission reduction goals (the so-called "nationally determined contributions" (NDCs)) based on their energy development plans, growth of carbon-intensive industries, and the economy as a whole [Makarov, Stepanov, 2018; Savaresi, 2016]. Basically, these goals are nothing more than benchmarks for the states declaring them. Moreover, even their full implementation will not make it possible to reach a temperature increase pathway of less than $2^{\circ} \mathrm{C}$ compared to the pre-industrial era [Climate Action Tracker, 2017]. Donald Trump's declaration on the withdrawal by the U.S. from the Paris Agreement makes the situation even worse.

In certain sense, the Paris Agreement delegates the definition of emission reduction pathways to the national level, leaving to international climate cooperation only the function of coordinating national climate policies. However, at the national level, mitigation policies will 
inevitably remain a derivative of the social and economic policies of individual countries that are at different stages of development and have different strategic priorities and tactical agendas [Victor, Jones, 2018]. This limits the scope for coordinated action by governments and civil societies on a global scale.

In developing countries, emissions growth is still closely associated with income growth. The surge in energy consumption does not occur at the stage of overcoming poverty (during which energy consumption is low). Rather, it is tied to later stages of development, leading to rapid motorization, wider use of air conditioning, complication of lifestyle, and increased mobility, among other trends. A failure to consider changes in the social structure of the economy and the different carbon footprints of various income groups will make ambitious reductions in emissions more difficult.

The established international climate change regime cannot prevent the spread of western consumer behaviour patterns to emerging economies, where large groups of people are entering the middle class and expanding their consumption of goods and services that are still produced using outdated carbon-intensive technologies. Nor can it prevent the carbon-intensive consumer behaviour of middle- and upper-income deciles in developed countries, which already follow this consumer model to the full extent. Even if considerable financial resources are accumulated, the solution to these problems is barely possible within the current system of international climate institutions.

First, the existing system of international cooperation is based on counting emissions by countries as a whole. It does not capture the forces driving the growth of emissions within each country. Decisions on specific emission reduction mechanisms (taxes, emissions trading, subsidies for the development of clean technologies, etc.) are also made at the country level. At the same time, the goal to reduce emissions in many economies contradicts other national goals including raising living standards, ensuring energy security, promoting economic growth, and so on. The story is even more complicated due to electoral cycles that can impede long-term decisions.

Second, the international climate change regime is based on tracking domestic emissions (so-called production-based emissions), and not those emissions that occur in the production of goods consumed in a country (so-called consumption-based emissions) [Davis, Caldeira, 2010; Makarov, Sokolova, 2014]. Changes in income levels and consumption patterns affect production-based emissions to a much lesser extent, as long as some emissions are generated for the production of goods exported to other countries (in the leading emerging economies the share of emissions embodied in exports can be very high). Since the relationship between production-based emissions and the social structure of a society is not direct and obvious, the issue of accounting for emissions by income group has traditionally received little attention. At the same time, while the relationship between the social structure and consumption-based emissions is direct and strong, the consumption-based approach remains beyond the interests and responsibilities of international organizations [Steininger et al., 2014].

Third, the current system of international institutions is based on a polycentric approach [Cole, 2015; Oberthür, 2016; Ostrom, 2014]. Today, the list of international organizations which deal with climate change include a range of institutions within the UN Framework Convention on Climate Change, the World Bank (financing climate-related projects), the UN Environment Programme (UNEP) and others. The Group of 20 and BRICS are also paying more and more attention to climate change issues. Climate change research is the responsibility of the Intergovernmental Panel on Climate Change (IPCC). Certain aspects of the problem are dealt with by specialized international organizations such as the Food and Agriculture Organization 
(FAO), the UN Development Programme (UNDP), the International Energy Agency (IEA) and the World Trade Organization (WTO). Combating climate change is also a part of the SGDs adopted at the UN General Assembly. In parallel, there is a network of highly influential and financially supported international non-governmental organizations (World Wildlife Fund (WWF), Greenpeace, Oxfam, etc.) as well as various research institutes. Finally, significant efforts to combat climate change are made in different countries, regions and municipalities, as well as at the level of individual companies.

This diversity has its advantages, such as greater flexibility and independence from the decisions of specific individuals. At the same time, it is characterized by a lack of coordination between different institutions. This makes it extremely difficult to balance the inherently conflicting goals of reducing poverty/inequality and reducing greenhouse gas emissions.

\section{Modifications to Global Governance in Climate Change Based on the Decile Emission Management Approach}

It would be useful to supplement the existing system of institutions with add-ons that will allow: - coordination of work on the achievement of two SGDs - climate action (goal 13) and reducing inequality (goal 10) - in order to prevent conflict between them, and strengthening of the interaction of institutions addressing inequality and climate change;

- creation of a system of incentives for wealthy households and households with growing incomes that will encourage them to restructure their consumption in accordance with the requirements of emission reduction; and

- access to relatively less carbon-intensive technologies and consumer behaviour patterns for households on the threshold of a transition to a consumer society.

The implementation of these goals is possible through the following mechanisms.

\section{Consolidation of Efforts by Scientists and Experts}

It is appropriate to create a special working group that monitors countries' emissions and operates under the auspices of the World Bank (possibly in collaboration with the UN Department of Social and Economic Affairs, the IPCC, the Organisation for Economic Co-operation and Development (OECD) and the IEA). Its functions could focus on several aspects of emissions accounting. First, it could consider consumption-based emissions. Strictly speaking, it is not important where greenhouse gases are emitted, but rather for what purpose they are emitted. Emissions accounting based exclusively on the production approach leads to carbon leakage [Aichele, Felbermayr, 2013] and prevents the rise of climate action ambitions even in enthusiastic societies. Developed countries which would no longer have carbon-intensive production would continue to report on green development, although their emissions from consumption as well as global emissions would keep growing. Second, it could take account of the structure of emissions in relation to different income groups within countries, as well as changes in this structure resulting from economic development. Third, it could make projections of emissions by country taking into account expected economic growth and the evolution of income distribution within countries.

Ultimately, conceptualizing a quintile/decile approach to analyzing country-level emissions could help the special working group to identify key population groups whose incomes in the future will determine the dynamics of emissions in a given country. 


\section{Development of a New Regulatory System for Income Groups That Have Achieved Income Thresholds}

Incentives should be calibrated, starting with some signaling measures for groups that are on the threshold of joining consumer society, and ending with a full-fledged carbon tax on high-income deciles. Such a system of redistribution is fiscally progressive, but it is different from progressive income taxes in that revenues are spent on specific climate-related measures.

Linking the social structure of society with the concept of consumption-based emissions, it is possible to divide countries' income quintiles/deciles into several groups with corresponding policy measures.

Group A includes deciles above the threshold of GDP per capita of $\$ 15,000$ (PPP, constant 2011 Int1\$) which corresponds approximately to the level of development of "middle-income countries" according to the classification scheme of the International Bank for Reconstruction and Development (IBRD). This group is characterized by increased use of vehicles and motor fuels, increased consumption of durable goods, in particular heating and cooling systems, and growing mobility, among other things [Grigoryev, Pavlyushina, 2019]. Entry to the group is followed by a fundamental shift in the patterns of everyday consumption, as well as by a surge in the consumption of public services and the use of public buildings.

Regulatory measures targeting this group should be signaling in nature, including carbon labeling of products, carbon certification of projects, voluntary carbon pricing, and measures to increase public awareness (education programmes).

Group B includes deciles above the threshold of GDP per capita of $\$ 25,000$ (PPP, constant 2011 Int1\$) which corresponds approximately to the level of "upper-middle income countries" according to the IBRD's classification. This income level is associated with the transition to large volumes of consumption of energy-intensive goods and services. This threshold is being met by the high-income groups in the developing world which are guided by the "western lifestyle." The rapid growth of wealth serves as a prerequisite for the intermittent growth of personal consumption, including energy consumption.

The regulatory system for this group should include intermediate incentive mechanisms: some elements of carbon pricing that are not yet punitive in nature. In essence, these measures should be a hybrid combining voluntary donations with the full carbon price in the form of a carbon tax or an emissions trading system.

Group C includes deciles above the threshold of per capita GDP of $\$ 40,000$ (PPP, constant 2011 Int1\$) which corresponds approximately to the current income of the upper-income deciles in developed countries and the richest deciles in emerging economies. These groups have an opportunity to change their consumption patterns for the better. They can afford a balanced diet, modern homes, and healthier lifestyles. The shift toward energy-efficient homes and hybrid/electric vehicles may lead to some slowdown in the growth of energy consumption compared with lower income groups.

The system of regulatory measures for this group should include the full price of carbon, which can take various forms: a carbon tax or a carbon sales tax (VAT) with tax deductions for low-income groups of the population; excise and/or carbon duties on goods consumed by upper-income groups; progressive income tax, and so on. The measures may vary with respect to distribution of income, features of the fiscal system, the role of other taxes, and features of individual national economies.

The described differentiation of income deciles in the leading countries was carried out on the basis of a modified decile indicator of income inequality, attaching a certain amount of production per capita to each decile in proportion to the decile income distribution [Grigoriev, Salmina, 2013]. The proposed indicator - imputed decile GDP per capita - indicates the level of GDP per capita of households which belong to a specific decile (in a given country) under the assumption that the 
share of decile income is equal to the share of decile productivity (contribution to the country's GDP) [Grigoriev, 2016]. Based on the calculation of the imputed decile GDP per capita, the following distribution of carbon regulation measures is proposed for different countries (Table 7).

Table 7. The Proposed Threshold System for Simulating Emission Reductions for Various Income Quintiles by G20 Countries, 2015*

\begin{tabular}{|c|c|c|c|c|c|c|}
\hline & \multicolumn{3}{|c|}{ Imputed Decile GDP per Capita, \$ Thousands } & \multicolumn{3}{|c|}{$\begin{array}{l}\text { Quintile Number From Which } \\
\text { Certain Incentive Measures Start }\end{array}$} \\
\hline & In the Whole Country & 5 Quintile & 10 Decile & $\mathbf{A}$ & B & $\mathbf{C}$ \\
\hline Argentina & 18.9 & 22.5 & 29.0 & 3 & 4 & 5 \\
\hline Australia & 41.4 & 43.6 & 54.9 & 1 & 2 & 3 \\
\hline Canada & 40.7 & 41.7 & 52.4 & 1 & 2 & 4 \\
\hline France & 37.3 & 38.5 & 50.1 & 1 & 3 & 4 \\
\hline Germany & 42.7 & 41.2 & 50.6 & 1 & 2 & 4 \\
\hline Indonesia & 9.7 & 11.5 & 15.4 & 5 & - & - \\
\hline Italy & 35.2 & 36.7 & 46.3 & 2 & 3 & 4 \\
\hline Japan (2008) & 36.3 & 36.0 & 44.9 & 2 & 3 & 4 \\
\hline Mexico & 16.3 & 22.2 & 32.4 & 4 & - & 5 \\
\hline Turkey & 18.8 & 21.8 & 28.7 & 3 & - & 5 \\
\hline Great Britain & 36.7 & 36.7 & 45.2 & 2 & 3 & 4 \\
\hline U.S. & 51.0 & 59.2 & 76.9 & 1 & 2 & 3 \\
\hline \multicolumn{7}{|c|}{ BRICS } \\
\hline Brazil & 15.2 & 21.3 & 30.8 & 4 & 5 & - \\
\hline Russia & 24.9 & 30.1 & 40.1 & 3 & 4 & 5 \\
\hline India & 4.6 & 5.1 & 6.9 & - & - & - \\
\hline China & 11.1 & 13.3 & 17.5 & - & 5 & - \\
\hline South Africa & 12.2 & 21.1 & 31.4 & - & - & 5 \\
\hline
\end{tabular}

Source: [World Bank, n. d. (authors' calculations)].

Note: *The table includes data for G20 countries except Korea, Saudi Arabia and the EU.

All of the proposed measures should be based on the principles of transparency, involve clear mechanisms of fundraising, and focus on commonly shared objectives. The measures taken by each country should be declared in advance, as in the system of nationally determined contributions (NDC) used in the Paris Agreement.

In other words, states should declare not only the targets (like the current NDCs), but also the tools of emission reduction which would be employed. These tools do not have to be reintroduced - existing taxes may be taken into account in order to avoid triple taxation (progressive income tax in some countries, tax on energy-intensive goods, and new incentives). With a new system of reporting, it would be much easier to check whether the principle of additionality is respected, i.e., whether the undertaken efforts are new. In the case of declaring targets alone, the latter can be achieved for natural reasons, without any additional efforts, but it is almost impossible to prove it. 


\section{Building a System to Accumulate Funds}

The funds that could be accumulated using taxes on high deciles, on the one hand, depend on the model calculations dedicated to ensuring that the temperature does not rise above $2^{\circ} \mathrm{C}$; this will inevitably be a subject of negotiations between governments and civil society. Obviously, the amount of funds that could be agreed to by all parties cannot be too high. It is unlikely that the climate tax on wealthy deciles will raise funds sufficient to fulfill the formal purpose of the Paris Agreement, and one should not necessarily strive for that at any cost. It is critically important that the funds raised are above the symbolic level and reflect a compromise between governments, business and civil society. At the early stage, the introduction of the principle of a climate tax on wealthy deciles is more important than the size of the tax. Further, pressure from civil society and political competition will ensure the gradual increase of this tax in many leading countries.

There are two ways to use the collected funds. They can be complementary and implemented in a certain proportion. First, there could be a transfer of funds to a special international climate fund, to be further allocated to finance climate projects that meet the set of criteria (see below). The World Bank could act as the managing body of the fund, and it would guarantee the transparency of allocation. Second, direct investments could be made by countries in projects that meet the same criteria as those funded by the international climate fund. Determining the direction of spending funds without mediation from the climate fund would allow countries to align a solution to climate problems with their own socio-economic or political goals. However, in this case each project must be accredited by a specialized unit of the fund.

BRICS countries are key actors in the described process. Moreover, they may initiate it. For BRICS countries, the major condition of low-carbon development is its inclusiveness and consistence with other development goals such as eliminating poverty, reducing inequality and ensuring universal access to basic goods, including energy. The conventional model of climate policies based on carbon pricing and subsidizing renewables has been developed and applied relatively successfully in the western world; however, it hardly meets these criteria. The French "yellow vests" movement shows that achieving low-carbon ambitions is a challenge even in the developed world. In BRICS countries, where societies are already highly unequal and there is a need to weaken any fiscal load on the poor, this model is especially difficult to apply. BRICS countries require some strong alternatives to be put into place; linking carbon pricing to progressive income taxation may be one of them.

Moreover, BRICS countries already have some joint institutions which may give them the opportunity to launch their own mechanisms for climate funding and redistribution instead of relying on global ones. For instance, funds accumulated through a progressive carbon tax may be allocated collectively on a project basis via the New Development Bank.

\section{Revision of Criteria for Climate Financing}

Funds should be directed mainly to two project types that are not covered by conventional development finance or funds already specified in the Paris Agreement. First, funding should support those projects that: impact the carbon intensity of consumption by groups approaching the threshold values of income; support the cost of providing modern technology and staff training, and; widen education to the respective developing countries. Second, funding should also support projects focused on adaptation in countries where the proportion of poor people is high, and the consequences of climate change may lead to a humanitarian catastrophe.

The source for these investments could be the $\$ 100$ billion per year that is supposed to be mobilized as climate aid by 2020 (via bilateral aid agencies, international development banks 
and private initiatives), with further increases in funds in the 2020s. The directions for spending have not yet been determined, and an analysis of the dependence of consumption of carbonintensive products on incomes will make it possible to clarify efficient criteria for selecting specific projects. Some of the funds are already there; in 2016 there was more than $\$ 55$ billion, and in 2018 there was around $\$ 80$ billion. However, attempts to officially define the direction for spending face resistance by developed-country donors. Other possible sources for investments include a new international climate fund, formed by a climate tax on wealthy deciles, and funds provided by individual countries that prefer to independently finance projects accredited by the international climate fund.

\section{Conclusion}

The idea of a carbon tax on high-income strata by individual, primarily BRICS, countries or on a global basis will require an action plan. Politically, the accumulation of funds sufficient to prevent a temperature increase above $2^{\circ} \mathrm{C}$ can hardly be implemented right away at the global level, especially given the current extent of conflict in the international system. The proposed measures are unlikely to be unconditionally accepted by all countries participating in climate regulation because such measures will require the transfer of a significant part of state sovereignty to the supranational level.

At the same time, in the long run the transition to the proposed regulatory system is quite possible for the leading countries. It may be supported by the most active participants in the international climate regime - EU countries and other developed economies (where the share of relatively high income groups is greater), which have more homogeneous interests and are not numerous in comparison to the number of all participants in climate negotiations within the UN. At the same time, it will not affect the low- or middle-income groups by aggravating the problem of poverty or slowing down economic growth in developing economies (especially considering that funded projects will be implemented in those countries). It will also help mitigate the problem of inequality in western economies, which comes to the fore in the political agenda and requires action from political elites.

For BRICS countries the proposed mechanisms may be the instruments of transition toward inclusive low-carbon development - an objective that cannot be achieved through conventional carbon policies. They are also consistent with the SDG agenda which suggests that environmental, social and economic problems should be considered together as a complex issue to be solved jointly.

Launching the proposed system of measures, at least as a framework (starting with monitoring emissions in terms of deciles/quantiles and developing general principles for a climate tax on high-income groups), could play an important role in mitigating the climate change problem. Given the fact that growing inequality is becoming an important factor that hinders economic development in many countries, a progressive tax may become more attractive in the coming years. And it would be beneficial if it is implemented with climate-oriented modifications.

Taking into account the fact that the problem of inequality is becoming more acute, and given the incompatibility of reducing inequality and combating climate change, the solution to both problems is more likely to have a common ground. Even if the proposed system of measures is introduced as a framework, it will attract the attention of many political and civil society leaders. In the future, they would contribute to its full implementation. 


\section{References}

Aichele R., Felbermayr G. (2013) The Effect of the Kyoto Protocol on Carbon Emissions. Journal of Policy Analysis and Management, vol. 32, no 4, pp. 731-57. Available at: https://doi.org/10.1002/pam.21720 (accessed 10 February 2020).

Bell D. (1976) The Coming of the Post-Industrial Society. The Educational Forum, vol. 40, no 4, pp. 574-9. Available at: https://doi.org/10.1080/00131727609336501 (accessed 10 February 2020).

Chancel L., Piketty T. (2015) Carbon and Inequality: From Kyoto to Paris: Trends in the Global Inequality of Carbon Emissions (1998-2013) \& Prospects for an Equitable Adaptation Fund. Paris School of Economics. Available at: https://doi.org/10.13140/RG.2.1.3536.0082 (accessed 10 February 2020).

Climate Action Tracker (2017). Improvement in Warming Outlook as India and China Move Ahead, but Paris Agreement Gap Still Looms Large. Available at: http://climateactiontracker.org/publications/briefing/288/ Improvement-in-warming-outlook-as-India-and-China-move-ahead-but-Paris-Agreement-gap-still-loomslarge.html (accessed 10 February 2020).

Cole D.H. (2015) Advantages of a Polycentric Approach to Climate Change Policy. Nature Climate Change, vol. 5, no 2, pp. 114-8. Available at: https://www.repository.law.indiana.edu/facpub/1415 (accessed 10 February 2020).

Davies J., Shi X., Whalley J. (2014) The Possibilities for Global Inequality and Poverty Reduction Using Revenues From Global Carbon Pricing. The Journal of Economic Inequality, vol. 12, no 3, pp. 363-91. Available at: https://link.springer.com/article/10.1007/s10888-013-9259-2 (accessed 10 February 2020).

Davis S.J., Caldeira K. (2010) Consumption-Based Accounting of CO2 Emissions. Proceedings of the National Academy of Sciences, vol. 107, no 12, pp. 5687-92. Available at: https://doi.org/10.1073/pnas.0906974107 (accessed 10 February 2020).

Ehrlich P.R., Holdren J.P. (1971) Impact of Population Growth. Science, vol. 171, no 3977, pp. 1212-7. Available at: https://science.sciencemag.org/content/171/3977/1212 (accessed 10 February 2020).

Gates B., Gates M. (2016) Two Superpowers We Wish We Had. Annual Letter, Gates Notes, 22 February. Available at: https://www.gatesnotes.com/2016-Annual-Letter (accessed 10 February 2020).

Gore T. (2015) Extreme Carbon Inequality: Why the Paris Climate Deal Must Put the Poorest, Lowest Emitting and Most Vulnerable People First. Policy Paper, OXFAM International. Available at: https://www.oxfam. org/en/research/extreme-carbon-inequality (accessed 10 February 2020).

Grigoryev L.M. (2016) Social'noe neravenstvo v mire - interpretaciya neochevidnyh tendencij [Social Inequality in the World: The Interpretation of Non-Obvious Trends]. Journal of NEA, no 3, pp. 146-60. (in Russian)

Grigoryev L.M., Pavlyushina V.A. (2018) Mezhstranovoe neravenstvo: dinamika i problema stadij razvitiya [Inter-Country Inequality as a Dynamic Process and the Problem of Post-Industrial Development]. Voprosy Ekonomiki, no 7, pp. 5-29. (in Russian)

Grigoryev L.M, Pavlyushina V.A. (2019) Relative Social Inequality in the World: Rigidity Against the Economic Growth, 1992-2016. Russian Journal of Economics, vol. 5, no 1, pp. 46-66. Available at: https://doi. org/10.32609/j.ruje.5.35485.

Grigoryev L.M., Salmina A.A. (2013) Struktura social'nogo neravenstva sovremennogo mira: problemy izmereniya [The Structure of Social Inequality of the Modern World: Measurement Problems]. Sociological Journal, no 3, pp. 5-16. (in Russian)

Grunewald N. et al. (2012) The Carbon Footprint of Indian Households. Paper presented at the 32nd General Conference of the International Association for Research in Income and Wealth, Boston, 5-11 August. Available at: http://www.iariw.org/papers/2012/GrunewaldPaper.pdf (accessed 10 February 2020).

Han X., Chatterjee L. (1997) Impacts of Growth and Structural Change on CO2 Emissions of Developing Countries. World Development, vol. 25, no 3, pp. 395-407. Available at: http://www.sciencedirect.com/science/article/pii/S0305-750X(96)00110-6 (accessed 10 February 2020). 
Kaika D., Zervas E. (2013a) The Environmental Kuznets Curve (EKC) Theory: Part A: Concept, Causes and the CO2 Emissions Case. Energy Policy, vol. 62, pp. 1392-1402. Available at: http://www.sciencedirect.com/ science/article/pii/S0301421513007970 (accessed 10 February 2020).

Kaika D., Zervas E. (2013b) The Environmental Kuznets Curve (EKC) Theory: Part B: Critical Issues. Energy Policy, vol.62, pp. 1403-11. Available at: http://www.sciencedirect.com/science/article/pii/S0301421513007969 (accessed 10 February 2020).

Kaya Y. (1989) Impact of Carbon Dioxide Emission Control on GNP Growth: Interpretation of Proposed Scenarios. Response Strategies Working Group Memorandum, IPCC Energy and Industry Subgroup.

Li J., Wang Y. (2010) Income, Lifestyle and Household Carbon Footprints (Carbon-Income Relationship), A Micro-Level Analysis on China's Urban and Rural Household Surveys. Environmental Economics, vol. 1, no 2, pp. 44-71. Available at: https://businessperspectives.org/pdfproxy.php?item_id:3684 (accessed 10 February 2020).

Makarov I.A., Sokolova A.K. (2014) Ocenka uglerodoemkosti vneshnej torgovli Rossii [Evaluation of the Carbon Intensity of Russian Foreign Trade]. Economic Journal of the Higher School of Economics, vol. 18, no 3, pp. 477-507. Available at: https://ej.hse.ru/data/2014/11/19/1101018306/Макаров.pdf (accessed 10 February 2020). (in Russian)

Makarov I.A., Stepanov I.A. (2018) Parizhskoe klimaticheskoe soglashenie: vliyanie na mirovuyu energetiku i vyzovy dlya Rossii [Paris Climate Agreement: Impact on World Energy and Challenges for Russia]. Actual Problems of Europe, vol. 2, no 1, pp. 77-100. (in Russian)

Makarov I.A. (2018) Discrepancies Between Environmental Kuznets Curves for Production- and Consumption-Based CO2 Emissions. Research Paper No WP BRP199/EC/2018, Higher School of Economics. Available at: https://papers.ssrn.com/sol3/papers.cfm?abstract_id=3259100 (accessed 10 February 2020).

Milanovic B. (2016) Global Inequality: A New Approach for the Age of Globalization. Cambridge: Harvard University Press.

Mir G., Storm S. (2016) Carbon Emissions and Economic Growth: Production-Based Versus ConsumptionBased Evidence on Decoupling. Working Paper No 41, Institute of New Economic Thinking. Available at: https://www.ineteconomics.org/uploads/papers/WP_41-Storm-and-Mir_1.pdf (accessed 10 February 2020).

Oberthür S. (2016) Reflections on Global Climate Politics Post Paris: Power, Interests and Polycentricity. The International Spectator, vol. 51, no 4, pp. 80-94. Available at: https://doi.org/10.1080/03932729.2016.1242256 (accessed 10 February 2020).

Olivier J.G.J., Peters J.A.H.W. (2018) Trends in Global CO2 and Total Greenhouse Gas Emissions: 2018 Report. PBL Netherlands Environmental Assessment Agency. Available at: https://www.pbl.nl/en/publications/ trends-in-global-co2-and-total-greenhouse-gas-emissions-2018-report (accessed 10 February 2020).

Ostrom E. (2009) A Polycentric Approach for Coping With Climate Change. Annals of Economics and Finance, vol. 15, no 1, pp. 97-134. Available at: https://doi.org/10.1596/1813-9450-5095 (accessed 10 February 2020).

Piketty T. (2014) Capital in the Twenty-First Century. Cambridge: Harvard University Press.

Rosas J., Sheinbaum C., Morillon D. (2010) The Structure of Household Energy Consumption and Related CO2 Emissions by Income Group in Mexico. Energy for Sustainable Development, vol. 14, no 2, pp. 127-33. Available at: https://doi.org/10.1016/j.esd.2010.04.002 (accessed 10 February 2020).

Savaresi A. (2016) The Paris Agreement: A New Beginning? Journal of Energy \& Natural Resources Law, vol. 34, no 1, pp. 16-26. Available at: https://doi.org/10.1080/02646811.2016.1133983 (accessed 10 February 2020).

Shammin M.R., Bullard C.W. (2009) Impact of Cap-and-Trade Policies for Reducing Greenhouse Gas Emissions on U.S. Households. Ecological Economics, vol. 68, no 8-9, pp. 2432-8. Available at: https://doi. org/10.1016/j.ecolecon.2009.03.024 (accessed 10 February 2020).

Steininger K. et al. (2014) Justice and Cost Effectiveness of Consumption-Based Versus Production-Based Approaches in the Case of Unilateral Climate Policies. Global Environmental Change, vol. 24, no 1, pp. 75-87. Available at: https://doi.org/10.1016/j.gloenvcha.2013.10.005 (accessed 10 February 2020).

Stern D.I. (2017) The Environmental Kuznets Curve After 25 Years. Journal of Bioeconomics, vol. 19, no 1, pp. 7-28. Available at: https://link.springer.com/article/10.1007\%2Fs10818-017-9243-1 (accessed 10 February 2020). 
The Paris Agreement (2015). Adopted at the Twenty-First Session of the Conference of the Parties to the United Nations Framework Convention on Climate Change. Paris, 12 December. Available at: https://treaties. un.org/Pages/ViewDetails.aspx?src $=$ TREATY\&mtdsg_no $=X X V I I-7-d \& c h a p t e r=27 \& l a n g=$ en\&clang=_en (accessed 10 February 2020).

Uchiyama K. (2016) Environmental Kuznets Curve Hypothesis. Environmental Kuznets Curve Hypothesis and Carbon Dioxide Emissions. Tokyo: Springer.

United Nations Framework Convention on Climate Change (UNFCCC) (1992). Adopted at the Fifth Session of the Intergovernmental Negotiating Committee for a Framework Convention on Climate Change. New York, 9 May. Available at: http://unfccc.int/files/essential_background/background_publications_htmlpdf/application/pdf/conveng.pdf (accessed 10 February 2020).

Van Alstine J., Neumayer E. (2010) The Environmental Kuznets Curve. Handbook on Trade and the Environment (K.P. Gallagher (ed.)). Cheltenham: Edward Elgar. Available at: http://eprints.lse.ac.uk/30809/ (accessed 10 February 2020).

Victor D., Jones B. (2018) Undiplomatic Action: A Practical Guide to the New Politics and Geopolitics of Climate Change. Highlights from the Cross-Brookings Initiative on Energy and Climate. Available at: https:// www.brookings.edu/research/undiplomatic-action-a-practical-guide-to-the-new-politics-and-geopoliticsof-climate-change/ (accessed 10 February 2020).

Waggoner P.E., Ausubel J.H. (2002) A Framework for Sustainability Science: A Renovated IPAT Identity. Proceedings of the National Academy of Sciences, vol. 99, no 12, pp. 7860-5. Available at: https://doi.org/10.1073/ pnas.122235999 (accessed 10 February 2020).

White V., Roberts S., Preston I. (2010) Understanding 'High Use Low Income' Energy Consumers. Final Report to Ofgem, Centre for Sustainable Energy. Available at: https://www.ofgem.gov.uk/ofgem-publications/57558/high-use-low-income-energy-consumersfinal-report-nov-10-pdf (accessed 10 February 2020).

World Bank (n. d.). World Development Indicators. Available at: https://datacatalog.worldbank.org/dataset/ world-development-indicators.

World Resources Institute (n. d.). CAIT Historical Emissions Data (Countries, U.S. States, UNFCCC). Available at: https://www.wri.org/resources/data-sets/cait-country-greenhouse-gas-emissions-data (accessed 10 February 2020).

York R., Rosa E.A., Dietz T. (2003) STIRPAT, IPAT and ImPACT: Analytic Tools for Unpacking the Driving Forces of Environmental Impacts. Ecological Economics, vol. 46, no 3, pp. 351-65 Available at: http://www. res.ku.edu/ crgc/NSFWorkshop/Readings/STIRPAT_\%20IPAT\%20and\%20ImPACT.pdf (accessed 10 February 2020). 